\title{
Etiology of malign bone tumors
}

\author{
Malign kemik tümörlerinin etyolojisi
}

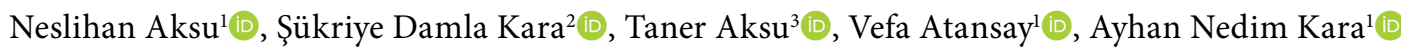 \\ Department of Orthopedics and Traumatology, Demiroğlu Bilim University Faculty of Medicine, İstanbul, Turkey \\ Department of Neurology, University of South Florida, Florida, USA \\ Department of Orthopedics and Traumatology, Bahçeşehir University Faculty of Medicine, İstanbul, Turkey
}

\begin{abstract}
Primary malignant bone tumors constitute a very small part of adult cancers. However, osteosarcomas constitute approximately half of all malignant bone tumors in ages between 15 to 29 years. This is followed by Ewing sarcoma primitive neuroectodermal tumors of bone and chondrosarcoma. Factors affecting malignant bone tumors include genetics, race, sex, growth and development age, radiotherapy treatment, radioactive substances, chemotherapy treatment, trauma, chemical substances, predisposing lesions, X-rays, and immune deficiency. Determining possible familial and genetic risk factors and predisposing agents and therefore informing families on avoiding physical and chemical exposure may be the most important factors in preventing malignancy. In this article, we aimed to discuss factors affecting the development of malignant bone tumors.
\end{abstract}

Keywords: Alkylating agent, bone cancer, chemical agent, chemotherapy, etiologic factors, malign bone tumor, radiotherapy.

\section{öz}

Erişkin kanserlerinin çok az bir kısmını primer malign kemik tümörleri oluşturur. Ancak, 15-29 yaşlar arasında bütün malign kemik tümörlerinin yaklaşık yarısını osteosarkomlar oluşturur. Bunu Ewing sarkomu/primitif nöroektodermal tümörleri ve kondrosarkom takip eder. Malign kemik tümörlerinde etkili faktörler; genetik, ırk, cinsiyet, büyüme ve gelişme çağı, radyoterapi tedavisi, radyoaktif maddeler, kemoterapi tedavisi, travma, kimyasal maddeler, predispozan lezyonlar, $\mathrm{X}$ ısınları, immün yetmezlik olarak sayılabilir. Olası ailesel ve genetik faktörlerin ve predispozan ajanların belirlenmesi ve aileleri fiziksel ve kimyasal maruziyetinden kaçınmaları hakkında bilgilendirmek maligniteyi önlemede en etkili faktörler olabilir. Bu yazıda, malign kemik tümörlerinin gelişimini etkileyen faktörleri tartışmayı amaçladık.

Anahtar sözcükler: Alkilleyici ajan, kemik kanseri, kimyasal ajan, kemoterapi, etyolojik faktörler, malign kemik tümörü, radyoterapi.

Primary malignant bone tumors comprise $3 \%$ of all cancers in adolescents and young adults. Osteosarcomas account for $48 \%$ of all malignant bone tumors between the ages 15-29. This is followed by Ewing sarcoma/primitive neuroectodermal tumor (bone PNET) at $27 \%$ and chondrosarcoma at $15 \%{ }^{[1]}$

Osteosarcoma is a tumor that produces osteoid. Presence and revealing of anaplastic stromal cells and their production of osteoid is diagnostic. Classic osteosarcoma presents as osteoblastic (50-78\%), chondroblastic (4-25\%), and fibroblastic (4\%). Aside from this, they may also manifest as telangiectatic (1-4\%), small-cell $(<1 \%)$, osteoclast-rich $(<1 \%)$, and periosteal and parosteal (2\%) types. ${ }^{[1]}$ Ewing sarcoma includes atypical Ewing sarcoma and peripheral primitive neuroectodermal tumor. They originate from the neural crest between the central axis and limb. Ewing sarcomas and chondrosarcomas are commonly seen in the central axis. ${ }^{[1]}$ 
Tumor development is multifactorial. Regardless of the tumor cause, impairment of the cell's genome occurs. Rather than mutation of a single gene, injury to more than one gene at once (genes that increase cell count, oncogens, tumor preventing genes, and DNA repairing genes) play a role in cancer development. ${ }^{[2]}$

Known risk factors of development of malignant bone tumors:

1- Race and geographic factors: Ewing sarcoma could be called a disease of white children. Race and ethnic origins carry different incidences. It has more frequent rates in the white race compared to Africans and African Americans. ${ }^{[1]}$

2- Genetic and familial history: Another potential mechanism of carcinogenesis is loss of tumor suppressor genes and their inactivation. These genes regulate cell growth and differentiation and prevent tumor-specific uncontrolled proliferation. The p53 gene is a well-known tumor suppressor gene located on chromosome $17 \mathrm{p}$ and its tumor association has been proven. ${ }^{[3]}$ Mutation of various tumor suppressor genes play a role in syndromes such as hereditary retinoblastoma, Li-Fraumeni syndrome, Rothmund-Thomson syndrome, Bloom syndrome, and Werner syndrome (adult progeria). ${ }^{[1]}$ More than 100 different genes and mutations of their gene series have been identified to be associated with cancer. Tumor suppressor genes account for one portion of these and the p53 gene is one of them. ${ }^{[4,5]}$ In human cancers, the p53 gene was identified as one of the genes to most commonly undergo mutation. As they lose activity due to mutations, increased risk of development of osteosarcomas and many other tumors usually manifest as osteosarcomas and soft tissue sarcomas due to abnormalities in the p53 and MDM2 genes. According to one experimental study, a mouse with Li-Farumeni carrying two non-functional p53 gene alleles had the risk of sudden tumor development. ${ }^{[6]}$ Tumor suppressor genes are sensitive to DNA injury and play a role as a physiological barrier in organisms. At the same time, they keep growth and metastasis caused by oncogenes and uncontrolled cell proliferation under control. Loss of tumor suppressor function leads to damage to the genome. Tumor suppressor activity is dominated by other cellular proteins or viral oncoproteins. P53 is located on the short arm of the $17^{\text {th }}$ chromosome. This gene encodes a $53 \mathrm{kD}$ (kilodalton) nuclear phosphoprotein that plays a role in the control of cell proliferation. Phosphoprotein p53 is known to be necessary in the cell cycle and carries vital importance in cell division. It also plays a role in DNA repair, DNA synthesis, cell differentiation, and programmed cell death (apoptosis). Inactivity of the p53 gene as a result of acquired mutations is responsible for the development and progression of many tumors. It has been associated with many different cancer types such as osteosarcoma and soft tissue sarcomas, meningioma, hepatocellular carcinoma, Burkitt lymphoma, colon, lung, stomach cancer, and ovarian myelodysplastic syndrome. P53-specific mutations have also been identified in the familial cancer syndrome known as Li-Fraumeni syndrome. Among identified changes to the p53 gene, $47 \%$ are point mutations, while deletion and insertions are less common. ${ }^{[4,5]}$ There is $\mathrm{Rb}$ (retinoblastoma) and p53 gene inactivation in most osteosarcomas. Heterozygosity loss in the $\mathrm{Rb}$ gene causes DNA injury and aggressive effect, halting production of proteins suppressing cell growth, leading to osteosarcoma development. ${ }^{[4,5]}$

Genes providing regulation of growth factor receptors are also associated with bone malignancies. Increased activity of these genes may lead to chronic cell proliferation and tumor development. ${ }^{[7]}$

Osteosarcomas are one of the commonly seen malignant bone tumors and the molecular pathologic process of this tumor is still unclear. Insulin-like growth factor-1 (IGF-1) is a fundamental hormone that plays a role in the development and function of many tissues. However, overexpression of IGF-1 and its receptor (IGF-1R) may affect the carcinogenesis of many tissues. It is also a risk factor for the development of many cancers, including osteosarcoma. ${ }^{[8]}$ Overexpression of IGF-1 and IGF-1R causes prolonged survival of tumor cells, their metastasis, and resistance to chemotherapeutic drugs. ${ }^{[8]}$

One recent study demonstrated that the biological markers $\mathrm{C}-\mathrm{X}-\mathrm{C}$ motif chemokine receptor 4 (CXCR4) and human epidermal growth factor receptor 2 (HER2), and the membrane 
molecule C44, which was first determined on lymphocytes and possesses important functions in cell adhesion and migration, had higher expression in high grade osteosarcomas compared to low-grade osteosarcoma cases. New studies on these biological markers as a prognostic factor in malignant osteosarcoma are being conducted. ${ }^{[9]}$

One study demonstrated that MDM2 oncogene amplification and overexpression increases MDM2-p53 binding causing p53 inactivity. Number of MDM2 copies multiplying from 2 to 3 were identified in 7 of 37 cases, in which osteosarcoma was detected in 5 of them. It was observed that MDM2 gene amplification occurred independently from p53 mutation. In summary of the study, $34 \mathrm{p} 53, \mathrm{Rb}$, and MDM2 changes were found in 26 of the 42 osteosarcoma cases. ${ }^{[10]}$

Li-Fraumeni syndrome is a rare familial cancer syndrome. It is characterized by tumor history in close relatives, onset of tumors at earlier than expected stage of life, and multiple primary tumors. Mutations of the p53 gene, especially codon 248 in exon 7 , have been identified. Usually the change in codon 248 is arginine to tryptophan. P53 mutation leads to pol III transcription causing Li-Fraumeni syndrome which leads to genetic predisposition and hereditary traits. ${ }^{[1]}$ One study compared 42 patients with soft tissue sarcoma and osteosarcoma to 42 children without cancer. These patients had no previous family history of cancer. Out of 204 first degree relatives, 6 had cancer. In the normal children, none of the 183 relatives had cancer. The results showed that $7.1 \%$ of pediatric patients with soft tissue sarcoma and osteosarcoma could be from Li-Fraumeni syndromed families. ${ }^{[12]}$

Osteosarcoma is also seen in two-sided hereditary retinoblastoma patients. Deletions and rearrangements of the $\mathrm{Rb}$ gene (tumor suppressor gene, recessive oncogene) on the $13^{\text {th }}$ chromosome may lead to osteosarcoma. ${ }^{[13,14]}$

A multicenter study conducted in the United States and Canada observed p53 mutations in $53 \%$ of osteosarcoma patients. HLA-A11 and HLA-B7 antigen expression rate was found more frequent in children with osteosarcoma in Spain. This high rate of HLA-A11 was also observed in Japan, where it was found. Meanwhile, the potential roles of the HLA-B7 antigen put forth by Barona et al. ${ }^{[15]}$ was not accepted by any other author.

Ewing sarcoma, like osteosarcoma, is not a component of Li-Fraumeni syndrome. One study indicated that breast cancer and melanoma was encountered in mothers of osteosarcoma patients under the age of 25 . The relationships between familial pediatric osteosarcoma and liver cancer, Ewing sarcoma and renal cancer, and giant-cell bone tumor and maternal breast cancer has been demonstrated. ${ }^{[16]}$

3- Gender and hormones: Malignant bone cancers are more common in males than in females. ${ }^{[1]}$ Two-thirds of Ewing sarcoma patients are male. Osteosarcoma is detected in females at a relatively earlier age compared to males. Aside from patients younger than nine years of age, osteosarcoma is more frequent in males than females. ${ }^{[1]}$ Malignant bone tumors are two times higher in males than females between ages 15-19. When malignancy is suspected in males, Ewing sarcoma has higher rate than osteosarcoma. ${ }^{[1]}$ It is believed that sudden development of bone cancer in Rottweiler breed dogs with breast and prostate cancer is due to the association between osteosarcoma and sex hormones. ${ }^{[17]}$

4- Herniations: Inguinal and umbilical herniations are widely researched birth anomalies. It was reported that umbilical and inguinal herniations was diagnosed at an earlier age in patients with Ewing sarcoma compared to control groups. ${ }^{[18-21]}$ A recent meta-analysis of 357 patients and 745 control group subjects and two additional case control studies reported that children with history of herniation were at higher risk of developing Ewing sarcoma. ${ }^{[19,21]}$ One study of 324 patients reported that Ewing sarcoma patients had high risk of inguinal herniation compared to population expectation. ${ }^{[20]}$

\section{5- Growth and Development stage:} Osteosarcoma frequency peaks twice: in the early adolescent period and over age $65 .{ }^{[1]}$ Ewing sarcoma is seen in childhood and adolescence, and is rare in the elderly. Chondrosarcoma is the second most common bone malignancy following osteosarcoma and is seen in adulthood and rarely in childhood. ${ }^{[1]}$ Pubertal development and bone growth are strongly associated with 
etiology. While which hormone is effective is unclear, gonadal sex hormones are believed to be important. In addition, results of analytical studies on height are conflicting with bone growth rate and puberty age. ${ }^{[1]}$

Individuals with osteosarcoma are usually observed to be taller than the general population. ${ }^{[22-25]}$ It has been come to the conclusion that rapid bone growth during the time of puberty leads to increased osteosarcoma risk. ${ }^{[25]}$ There is need for further research to understand the physiological mechanism responsible for this relationship. Female osteosarcoma cases were observed to have breast development and menarche earlier than control subjects. Two studies reported that osteosarcoma was diagnosed at an earlier age in females compared to males. ${ }^{[22,24]}$ Most of these studies have investigated the relationship between growth and development factors of early adolescence and risk of Ewing sarcoma. However, it was found that neither height nor weight was associated with Ewing sarcoma. ${ }^{[24,26]}$

6- Occupation: The relationship between malignant bone tumors and occupation has not been studied as often as soft tissue sarcomas. One European centered study reported increased risk of bone tumors (osteosarcomas and chondrosarcomas) in metal workers, tool manufacturers, and machine operators. ${ }^{[27]}$ This study also found increased risk of tumor development in brick workers and carpenters. Furthermore, products used in wood and mushroom production were also found to significantly increase risk of malignant bone tumor development. Individuals classified as machine and equipment manufacturers were also reported to be at high risk. Males classified as military workers, mariners, and drivers were also at risk of developing malignant bone tumors. ${ }^{[28]}$

7- Chemicals: The most important chemical causing malignant bone tumors is, again, alkalizing agents used in cancer chemotherapy. Cytotoxic effects of alkalizing agents occurs through the irreversible combination of electrophilic alkali root and the target molecule's nucleophilic portion. Chemotherapy (especially alkalizing agents) due to cancer treatment during childhood increases risk of osteosarcoma development. One case of synovial sarcoma following chemotherapy was reported. ${ }^{[29]}$ The patient underwent chemotherapy treatment due to rhabdomyosarcoma in the right scapular muscle, and developed osteosarcoma of the jaw and adrenocortical carcinoma six years later. The reason was attributed to p53 genetic mutation. CGT (Cytosine Guanine Thymine) of codon 273 had transformed to CAT (Cytosine Adenine Thymine). There were no additional reports of cancer in the family. ${ }^{[30]}$ There is a study that shows that children of mothers treated for nausea and vomiting during pregnancy are at high risk of developing Ewing sarcoma. ${ }^{[31]}$ Beryllium and methylcholantrene can lead to genetic changes and cause osteosarcoma. ${ }^{\text {[2] }}$

8- Physical factors: It is known that high dose of radiation significantly increases the risk of soft tissue sarcomas and bone tumors. In this group, ionizing radiation (radiotherapy) comes foremost. Ionizing radiation ( $\mathrm{X}$ and gamma rays, alpha and beta particles, protons, neutrons) has been found to cause somatic mutations resulting in tumors in humans and animal experiments. The type, dose, exposure time of radiation, and individual factors (age, hormonal status, immunity, etc.) also play a role. The latent period between radiation exposure and development of neoplasm may vary from a few years to 30-40 years. Neutrons and alpha particles are more dangerous than X-rays and gamma rays. ${ }^{[33-36]}$ Radiotherapy may lead to complications in bone, muscle, soft tissue, and nerve tissue as early as in three years. It may especially cause atrophy, bone development dysfunctions and anomalies, limb dysfunction, nerve paresthesia and paralyses, vasculitis, and thrombosis. The most common malignancy in bone soft tissue due to radiotherapy is osteosarcoma and malignant fibrous histiocytosis. ${ }^{[33-35]}$ It has been reported that ionizing radiation is responsible for $2 \%$ of osteosarcomas. ${ }^{[1]}$ Radiotherapy treatment applied to the pelvic region for various malignant causes has been shown to cause high risk of secondary sarcoma development. ${ }^{[6]}$ One patient was applied a total of 60 dose cGy to the right tibia and 40 dose cGY to the left tibia due to acute lymphocytic leukemia and developed osteosarcoma on the right tibia and malignant fibrous histiocytoma on the left tibia. These were aggressively structured secondary sarcomas. A large majority of 
patients undergoing radiotherapy for Ewing sarcoma develop secondary osteosarcomas. ${ }^{[29]}$ Sarcomas that develop secondary to radiation are aggressive and have poor prognosis. ${ }^{[37]}$ Another study found that patients with secondary sarcoma previously received mean 47 cGy dose radiation for treatment of other malignancies. ${ }^{[38]}$ In 429 patients undergoing radiotherapy due to malignant tumor, secondary neoplasm was reported in $5.4 \%$ of them and most emerged after about 10 years. Mean dose was 45 cGy. Secondary benign neoplasms originating from bone soft tissue are osteochondromas and lipomas. ${ }^{[34]}$

Radioactive materials are also known to cause malignant bone tumors. High dose of radium radioisotope causes osteosarcoma development in adults. Results of drinking low doses of it in water is unknown in adults and children. ${ }^{[1,35]}$ Animal studies have shown that repeated dose of $224 \mathrm{Ra}$ (radium) or single dose $227 \mathrm{Th}$ (thorium) may cause osteosarcoma. ${ }^{[39]}$ Thorium is relatively more carcinogenic than radium. A single dose of $5 \mathrm{muCi} / \mathrm{kg}$ (body weight) injection carries over 60\% tumor incidence. Repeated $224 \mathrm{Ra}$ injections has 92\% chance of causing tumors. Most of these tumors consist of well-differentiated bone-producing osteoblastic tissues. Half of the tumors are seen in the vertebrae, especially lumbar segments. They may also cause multifocal osteosarcomas. ${ }^{[40]}$ In followup of pediatric tuberculosis patients treated with $224 \mathrm{Ra}$, bone cancer is seen in $16 \%$ and most are osteosarcomas. ${ }^{[29]}$ Mouse experiments showed that $239 \mathrm{Pu}$ (plutonium) citrate, $223 \mathrm{Ur}$ (uranium), and $241 \mathrm{Am}$ (Americium) injection caused osteosarcoma and acute myeloid

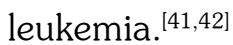

Physical traumas are also important causes. Many patients with malignant bone tumors have history of previous physical trauma. Previous trauma in the tumor site has been found to increase osteosarcoma risk. ${ }^{[43,44]}$

9- Viruses: Some viruses are cancerogenic. Up to 150 cancer-causing viruses have been found in animals. One-third of these are DNA viruses, while the rest are RNA-viruses. DNA viruses include Papovaviruses and Herpes viruses, Epstein Barr virus (EBV), Hepatitis $\mathrm{B}$, and Papilloma virus. RNA viruses include:
HTLV-1, mouse breast cancer, and mouse leukemia virus. Rous et al. reported in 1912 that viruses have a place in sarcoma etiology. Identified an RNA virus carrying an oncogenic gene known as V-Src named it the Rous sarcoma virus. ${ }^{[45]}$ Rous sarcoma virus (retrovirus or RNA virus) contains a gene called $\mathrm{V}-\mathrm{Scr}$ and has a proto-oncogene homologue [Pritchard, 1975]. Previously, with the discovery of the Simian virus 40 (SV40), the viral origin of osteosarcoma was shown with SV40. However, it was later concluded that polio virus vaccines were contaminated with SV40. ${ }^{[32]}$

10- Predisposing lesions: There are bone lesions that may potential become malignant despite being benign. Paget's disease is a risk factor for osteosarcoma. Fibrous dysplasia, Mafucci syndrome (hereditary multiple ectosis), and Ollier disease (multiple enchondromatosis) patients carry risk of developing chondrosarcoma. ${ }^{[4-48]}$ Some bone lesions such as osteochondroma, enchondroma, and exostosis are reported to be associated with increased chondrosarcoma incidence, though are rarely encountered in practice. ${ }^{[46,48]}$ Bone infarction and chronic osteomyelitis both carry potential to turn into secondary sarcoma. ${ }^{[1,48]}$ Malignancy (such as malignant fibrous histiocytoma) rarely develops from within bone infarction margins. ${ }^{[4]}$ Insufficiency fractures or stress fractures may sometimes stimulate osteogenic sarcoma originating from proximal tibial metaphysis. Posttraumatic osteolysis is identified in pubis of osteopenic elderly women and distal clavicular ends of athletes, especially weight-lifters. These two conditions may stimulate malignant bone tumor development with presence of radiological findings. ${ }^{[49]}$

11- Immunologic factors: The difficulty of researching cancer incidence in immune deficiency is that both illnesses are rare. ${ }^{[50]}$ Because bone cancers are also uncommon among all malignancies, it is even more challenging to establish the relationship between immune deficiency and bone cancers, and studies on this subject are limited. There are few publications which demonstrate the association between the immune system and cancer development. ${ }^{[51,52]}$ The immune system may easily identify foreign tissue antigens; however, the organism may not easily dispose 
of tumor tissue. In humans, about one billion cells multiply in one second, and somatically a few of these may develop hundreds of mutations in different cells per day. Cellular immunity plays a role in the immune response mechanism responsible for the disposal of these different cells. This is known as "immune control". The immune system controls immune development, and also provides immune response against tumor cells and antigens. When cellular immune response is suppressed, cancer development increases. Cancer cells that develop in hosts with strong immunity can be eliminated via cellular immunity. Immune deficiency transmitted though heredity and individuals using immunosuppressant drugs have increased rate of cancer. ${ }^{[51,52]}$

Factors that affect malignant bone tumors include: genetics, race, gender, growth and development period, radiotherapy treatment, radioactive materials, chemotherapy treatment, trauma, chemical agents, predisposing lesions, $\mathrm{X}$-rays, and immune deficiency. Determining familial and genetic cases and predisposing factors, and avoiding physical and chemical agents associated with malignancy are important factors in preventing malignancy. As research is conducted on this subject, available information with increase. In this article, we aimed to present the factors effective in the development of malign bone tumors.

\section{Declaration of conflicting interests}

The authors declared no conflicts of interest with respect to the authorship and/or publication of this article.

\section{Funding}

The authors received no financial support for the research and/or authorship of this article.

\section{REFERENCES}

1. Mascarenhas L, Siegel S, Spector L. Malignant bone tumors. Bethesda: National Cancer Institute; 2012.

2. Yokus B. ve Ülker DÜ. Kanser biyokimyası. Dicle Üniv Vet Fak Derg 2012:1:7-18.

3. Varley JM, Evans DG, Birch JM. Li-Fraumeni syndrome--a molecular and clinical review. Br J Cancer 1997;76:1-14.

4. Johnson AS, Couto CG, Weghorst CM. Mutation of the p53 tumor suppressor gene in spontaneously occurring osteosarcomas of the dog. Carcinogenesis 1998;19:213-7.
5. Savage SA, Burdett L, Troisi R, Douglass C, Hoover RN, Chanock SJ. Germ-line genetic variation of TP53 in osteosarcoma. Pediatr Blood Cancer 2007;49:28-33.

6. Hung J, Anderson R. p53: functions, mutations and sarcomas. Acta Orthop Scand Suppl 1997;273:6873.

7. Chandra A, Lan S, Zhu J, Siclari VA, Qin L. Epidermal growth factor receptor (EGFR) signaling promotes proliferation and survival in osteoprogenitors by increasing early growth response 2 (EGR2) expression. J Biol Chem 2013;288:20488-98.

8. Li YS, Liu Q, He HB, Luo W. The possible role of insulin-like growth factor-1 in osteosarcoma. Curr Probl Cancer 2019;43:228-35.

9. Ma Q, Zhou Y, Ma B, Chen X, Wen Y, Liu Y, et al. The clinical value of CXCR4, HER2 and CD44 in human osteosarcoma: A pilot study. Oncol Lett 2012;3:797-801.

10. Miller CW, Aslo A, Won A, Tan M, Lampkin B, Koeffler HP. Alterations of the p53, Rb and MDM2 genes in osteosarcoma. J Cancer Res Clin Oncol 1996;122:559-65.

11. Stein T, Crighton D, Boyle JM, Varley JM, White RJ. RNA polymerase III transcription can be derepressed by oncogenes or mutations that compromise p53 function in tumours and $\mathrm{Li}$-Fraumeni syndrome. Oncogene 2002;21:2961-70.

12. Carnevale A, Lieberman E, Cárdenas R. Li-Fraumeni syndrome in pediatric patients with soft tissue sarcoma or osteosarcoma. Arch Med Res 1997;28:383-6.

13. Kleinerman RA, Tucker MA, Tarone RE, Abramson $\mathrm{DH}$, Seddon JM, Stovall M, et al. Risk of new cancers after radiotherapy in long-term survivors of retinoblastoma: an extended follow-up. J Clin Oncol 2005;23:2272-9.

14. Kleinerman RA, Tucker MA, Abramson DH, Seddon JM, Tarone RE, Fraumeni JF Jr. Risk of soft tissue sarcomas by individual subtype in survivors of hereditary retinoblastoma. $\mathrm{J}$ Natl Cancer Inst 2007;99:24-31.

15. Barona P, Sierrasesúmaga L, Antillón F, Villa-Elízaga I. Study of HLA antigens in patients with osteosarcoma. Hum Hered 1993;43:311-4.

16. Ji J, Hemminki K. Familial risk for histology-specific bone cancers: an updated study in Sweden. Eur J Cancer 2006;42:2343-9.

17. Cooley DM, Beranek BC, Schlittler DL, Glickman NW, Glickman LT, Waters DJ. Endogenous gonadal hormone exposure and bone sarcoma risk. Cancer Epidemiol Biomarkers Prev 2002;11:1434-40.

18. Valery PC, McWhirter W, Sleigh A, Williams G, Bain C. A national case-control study of Ewing's sarcoma family of tumours in Australia. Int $\mathrm{J}$ Cancer 2003;105:825-30.

19. Valery PC, Holly EA, Sleigh AC, Williams G, Kreiger $N$, Bain C. Hernias and Ewing's sarcoma family of 
tumours: a pooled analysis and meta-analysis. Lancet Oncol 2005;6:485-90.

20. Cope JU, Tsokos M, Helman LJ, Gridley G, Tucker MA. Inguinal hernia in patients with Ewing sarcoma: a clue to etiology. Med Pediatr Oncol 2000;34:195-9.

21. Winn DM, Li FP, Robison LL, Mulvihill JJ, Daigle AE, Fraumeni JF Jr. A case-control study of the etiology of Ewing's sarcoma. Cancer Epidemiol Biomarkers Prev 1992;1:525-32.

22. Longhi A, Pasini A, Cicognani A, Baronio F, Pellacani A, Baldini $\mathrm{N}$, et al. Height as a risk factor for osteosarcoma. J Pediatr Hematol Oncol 2005;27:314-8.

23. Gelberg KH, Fitzgerald EF, Hwang S, Dubrow R. Growth and development and other risk factors for osteosarcoma in children and young adults. Int $\mathrm{J}$ Epidemiol 1997;26:272-8.

24. Cotterill SJ, Wright CM, Pearce MS, Craft AW. Stature of young people with malignant bone tumors. Pediatr Blood Cancer 2004;42:59-63.

25. Mirabello L, Pfeiffer R, Murphy G, Daw NC, PatiñoGarcia A, Troisi RJ, et al. Height at diagnosis and birth-weight as risk factors for osteosarcoma. Cancer Causes Control 2011;22:899-908.

26. Pendergrass TW, Foulkes MA, Robison LL, Nesbit ME. Stature and Ewing's sarcoma in childhood. Am J Pediatr Hematol Oncol 1984;6:33-9.

27. Merletti F, Richiardi L, Bertoni F, Ahrens W, Buemi A, Costa-Santos C, et al. Occupational factors and risk of adult bone sarcomas: a multicentric case-control study in Europe. Int $\mathrm{J}$ Cancer 2006;118:721-7.

28. Pukkala E, Martinsen JI, Lynge E, Gunnarsdottir HK, Sparén P, Tryggvadottir L, et al. Occupation and cancer - follow-up of 15 million people in five Nordic countries. Acta Oncol 2009;48:646-790.

29. Kudawara I, Araki N, Myoui A, Uchida A, Fukuda H, Yoshikawa H. Synovial sarcoma after chemotherapy for osteosarcoma: a case report. Clin Orthop Relat Res 2004;418:198-201.

30. Khayat CM, Johnston DL. Rhabdomyosarcoma, osteosarcoma, and adrenocortical carcinoma in a child with a germline p53 mutation. Pediatr Blood Cancer 2004;43:683-6.

31. Fathie K, Ghadrian P, Emard JF. Epidemiology of Bone Cancer: An Overview. The American Academy of Neurological and Orthopaedic Surgeons; 2012.

32. Broadhead ML, Clark JC, Myers DE, Dass CR, Choong PF. The molecular pathogenesis of osteosarcoma: a review. Sarcoma 2011;2011:959248.

33. Paulino AC. Late effects of radiotherapy for pediatric extremity sarcomas. Int $\mathrm{J}$ Radiat Oncol Biol Phys 2004;60:265-74

34. Paulino AC, Fowler BZ. Secondary neoplasms after radiotherapy for a childhood solid tumor. Pediatr Hematol Oncol 2005;22:89-101.

35. Sheppard DG, Libshitz HI. Post-radiation sarcomas: a review of the clinical and imaging features in 63 cases.
Clin Radiol 2001;56:22-9.

36. Virtanen A, Pukkala E, Auvinen A. Incidence of bone and soft tissue sarcoma after radiotherapy: a cohort study of 295,712 Finnish cancer patients. Int $\mathrm{J}$ Cancer 2006;118:1017-21.

37. Matsuo $T$, Sugita $T$, Shimose $S$, Kubo $T$, Yasunaga Y, Hiyama E, et al. Postradiation malignant fibrous histiocytoma and osteosarcoma of a patient with high telomerase activities. Anticancer Res 2005;25:2951-5.

38. Koshy M, Paulino AC, Mai WY, Teh BS. Radiationinduced osteosarcomas in the pediatric population. Int J Radiat Oncol Biol Phys 2005;63:1169-74.

39. Heidenreich WF, Müller WA, Paretzke HG, Rosemann M. Bone cancer risk in mice exposed to 224Ra: protraction effects from promotion. Radiat Environ Biophys 2005;44:61-7.

40. Gössner W, Hug O, Luz A, Müller WA. Experimental induction of bone tumors by short-lived boneseeking radionuclides. Recent Results Cancer Res 1976;54:36-49.

41. Ellender $M$, Harrison JD, Pottinger $H$, Thomas $\mathrm{JM}$. Induction of osteosarcoma and acute myeloid leukaemia in $\mathrm{CBA} / \mathrm{H}$ mice by the alpha-emitting nuclides, uranium-233, plutonium-239 and amercium-241. Int J Radiat Biol 2001;77:41-52.

42. Oghiso Y, Yamada Y. The specific induction of osteosarcomas in different mouse strains after injections of 239Pu citrate. J Radiat Res 2003;44:125-32.

43. Dorrestijn O, Jutte PC. Osteosarcoma in the distal femur two years after an ipsilateral femoral shaft fracture: a case report. J Med Case Rep 2011;5:198.

44. Goyal S, Roscoe J, Ryder WD, Gattamaneni HR, Eden TO. Symptom interval in young people with bone cancer. Eur J Cancer 2004;40:2280-6.

45. Weiss RA, Vogt PK. 100 years of Rous sarcoma virus. J Exp Med 2011;208:2351-5.

46. Kivioja A, Ervasti H, Kinnunen J, Kaitila I, Wolf $\mathrm{M}$, Böhling T. Chondrosarcoma in a family with multiple hereditary exostoses. J Bone Joint Surg $\mathrm{Br}$ 2000;82:261-6.

47. Noël G, Feuvret L, Calugaru V, Hadadi K, Baillet F, Mazeron JJ, et al. Chondrosarcomas of the base of the skull in Ollier's disease or Maffucci's syndrome-three case reports and review of the literature. Acta Oncol 2004;43:705-10.

48. Aksu N, Erdem MN, Hiz VMM. Bening kemik lezyonlarinda maligniteye dönüşüm belirtileri. TOTBID 2007;6:109-14.

49. Heck RK, Toy PC. Bening bone tumors and nonneoplastic conditions simulating bone tumors. In: Canale ST, Beaty J, editors. Campbell's Operative Orthopaedics. Chapter 25. 12th ed. New York: Mosby; 2012. p. 859-86.

50. Kalkan G, Ersoy F. Yaygın değişken immün yetmezlik hastaları ve yakınlarında malignite sıklığı. Selçuk Üniversitesi Tıp Dergisi 2011;27:65-8. 
51. Cunningham-Rundles C, Siegal FP, CunninghamRundles S, Lieberman P. Incidence of cancer in 98 patients with common varied immunodeficiency. J Clin Immunol 1987;7:294-9.
52. Kinlen LJ, Webster AD, Bird AG, Haile R, Peto $\mathrm{J}$, Soothill JF, et al. Prospective study of cancer in patients with hypogammaglobulinaemia. Lancet 1985;1:263-6. 